\title{
Biochemical composition of the edible parts of the spider crab Schizophrys aspera in the Great Bitter Lake of the Suez Canal
}

\author{
Nesreen K. Ibrahim
}

Marine Sciences Department, Faculty of Science, Suez Canal University, Ismailia, Egypt. E-mail:kadry1339@yahoo.com.

\section{ABSTRACT}

Spider crab Schizophrys aspera (Brachyura: Majidae) from Great Bitter Lake of the Suez Canal was studied during the spawning season for total edible yield, moisture, total protein, total lipid and total carbohydrate in the edible tissue. Total edible yield, muscle yield and GSI yield in male and female spider crab were compared. Results showed that male muscle yield (32\%) was greater than that of female $(28 \%)$, whereas female GSI yield $(5.7 \%)$ was higher than that of male $(1.3 \%)$. No significant differences in total edible yield between both sexes. Regarding to moisture, it was noticed that the muscle moisture $(73.5 \%)$ was greater than that of the gonad (69.9 \%). Comparing between both sexes, it was detected that male muscle moisture $(76.5 \%)$ and male gonad moisture $(73.2 \%)$ were greater than that of female (74.9\% and $70.1 \%$, respectively). Study of the biochemical composition in spider crab showed that gonad had higher protein, lipid and carbohydrate levels than those of muscle. Also, it was noticed that there is a difference between male and female in biochemical composition. Female spider crab showed a higher levels of protein, lipid and carbohydrate than male. The present work concludes that muscle and gonad of this crab contain high level of protein and low level of lipid and carbohydrate. These results suggest that spider crab is healthy for human consumption and is also suitable for processing into different crab products.

Keywords: Schizophrys aspera, Great Bitter Lake, edible yield, biochemical composition.

\section{INTRODUCTION}

Crustaceans are high-valued marine resources and are considered luxury sea food items. Crabs are considered to be important shell fishery products and are worldwide consumed as food and feed supplements (Gökoalu \& Yerlikaya, 2003). $\mathrm{Crab}$ is unique in having easily digestible proteins and essential fatty acids in its composition (Cherif et al., 2008).

Proteins are present in almost all sea food; although often in small amount. The principal nutritional value of proteins is due to the presence of essential amino acids in the edible parts. Lipids play an important role during the development of decapod crustaceans, not only as a source of energy, but also as essential nutrients (Kanazewa et al., 1985).

The spider crab Maja brachydactyla showed a commercial importance in Spain, and they used to catch till it is overexploited on the NW coast of Spain. They solve the overfishing problem of this species by aquaculture (Andrés, 2007). The spider crab Schizophrys aspera (H. Milne Edwards, 1834) is found in Indo-pacific oceans from South and East Africa to Japan, Australia and Hawaii (Guinot, 1967). It is known as decorator crab. There are many small pieces of sponge, hydroids and barnacles attached to its carapace, legs and chelipeds (Ibrahim, 2007). The biology, 
fishery and toxicity of this species have been studied for the first time in Suez Cana (Ibrahim, 2007).

It was caught in Bitter Lake, Suez Canal by fishermen as by-catch of shell fish product (Ibrahim, 2007). Fishermen used to get rid of this crustacean group by breaking them with small hummers to avoid destroying their nets by the large chela and the spine attached to their body. Spider crabs are not commercial species as they are not consumed in the Egyptian fish markets and even are not exported abroad.

No information is available on the biochemical composition of various edible parts of spider crabs. Therefore, the aim of study was to provide information on the edible yield of the spider crab Schizophrys aspera. Also, the biochemical composition particularly total protein, total lipids and total carbohydrates of different edible parts were investigated in male and female spider crab. So, this study could demonstrate the nutritional values of the target spider crab for use in human food or as feed in fish farm.

\section{MATERIALS AND METHODS}

Bitter Lake is one of the most important water bodies of the Suez Canal Lakes (Fig. 1).

It contains about $80 \%$ of the waters of the canal system. The study area is laid between latitudes $30^{\circ} 10^{\prime}-30^{\circ} 26^{\prime} \mathrm{N}$, and longitudes $32^{\circ} 10^{\prime}-32^{\circ} 40^{\prime} \mathrm{E}$. The Great Bitter Lake is about $34 \mathrm{~km}$ length with a maximum width of $13 \mathrm{~km}$. The maximum temperature recorded in summer (July and August) was $30^{\circ} \mathrm{C}$ whereas the minimum was $20^{\circ} \mathrm{C}$ in January (Ibrahim, 2007). A total of 150 specimens of adult Schizophrys aspera were caught during the spawning season in the period from June to September 2013 by the fishermen as a by- catch. Specimens were collected from the fishing sites in Deversoir, Great Bitter Lake by the crab net operated in this site (Fig. 1). Crabs were preserved in $4 \%$ formalin in plastic containers and transported to the laboratory at Marine Sciences Department, Faculty of Science, Ismailia, Egypt. Upon arrival at the laboratory, sexes were differentiated and each crab was weighed to the nearest 0.1 g. using an electric balance.

The muscle yield, gonad somatic index (GSI) and the total edible yield of the crab were calculating using the following formulas:

Muscle yield $(\%)=$ muscle wet weight $/$ total body weight $\times 100$

GSI $(\%)=$ gonad wet weight $/$ total body weight $\times 100$

Total edible yield $(\%)=$ muscle yield $(\%)+$ GSI $(\%)$

The moisture of all specimens was measured by calculating the tissue weight difference after drying in an oven at $105^{\circ} \mathrm{C}$ until constant weight is reached (AOAC, 2012). Total protein (TP) was analyzed using Kjeldahl method according to AOAC procedures (AOAC, 2012). Total lipid (TL) was extracted by chloroform-methanol and quantified using the method described by Folch (1957). Total carbohydrate (TC) content was determined using phenol-sulphuric acid method (Kochert, 1978).

One way analysis of variance (ANOVA) was performed using SYSTAT (V. $10.2 .05,2002$ ) program to determine the relation between total yield, moisture and biochemical composition and both crab sexes. Also, determine significance of biochemical analysis in different edible parts of crab (muscle and gonad). 


\section{RESULTS}

\section{Total yield}

A total of 150 specimens had been studied to detect the total edible yield, muscle yield and gonado somatic index (GSI). The total edible yield of both male and female spider crab is represented in Table 1 . Male muscle yield (32\%) was greater than that of female (28\%), whereas GSI of female (5.7\%) was higher than that of male $(1.3 \%)$. Generally, one way ANOVA factor showed that there was no significant difference in total edible yield between both sexes.

\section{Moisture in $S$. aspera}

Moisture in male and female crabs are represented in Table 2 and illustrated in Fig. 2 Generally it was noticed that the moisture in the muscle $(73.5 \%)$ was greater than that of the gonad (69.9\%). Regarding to sexes, it was detected that male muscle moisture $(76.5 \%)$ and male gonad moisture $(73.2 \%)$ was greater than that of female (74.9 \% and $70.1 \%$, respectively). One way ANOVA indicates significant difference between moisture of muscle and gonad, also between male and female crabs.

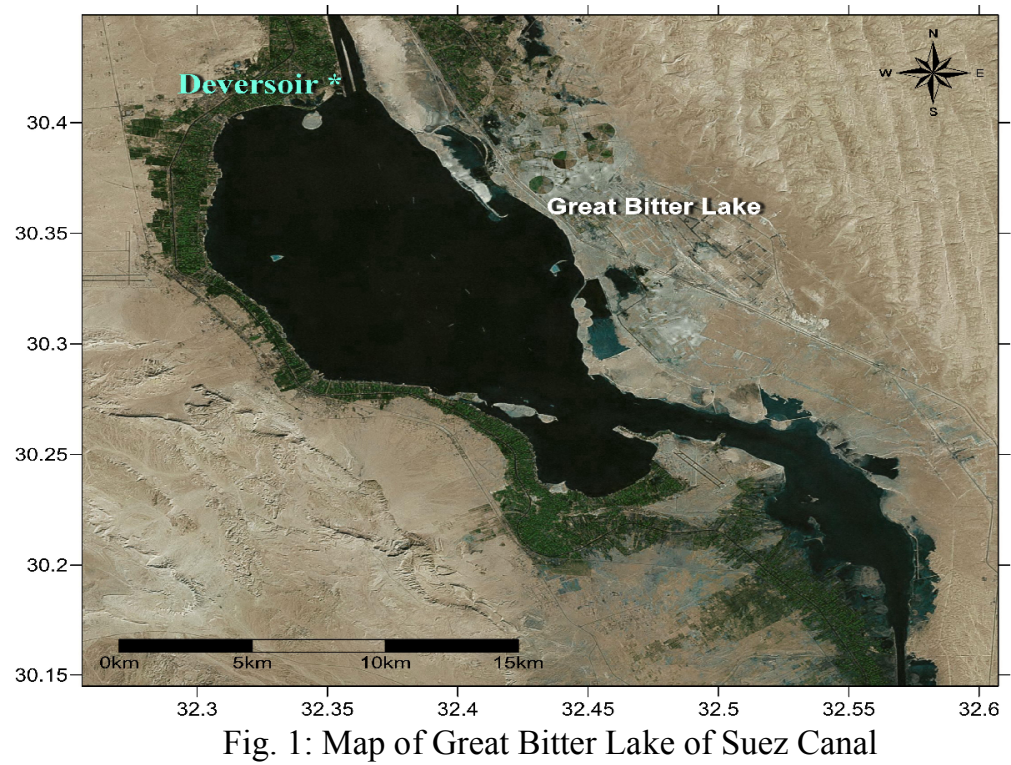

Table 1. Percentage of total edible yield in male and female S. aspera in Great Bitter Lake.

\begin{tabular}{|c|c|c|c|c|}
\hline \multirow[t]{2}{*}{ Yield \% } & \multicolumn{4}{|c|}{ Sex } \\
\hline & $\mathbf{n}$ & $\begin{array}{l}\text { Male } \\
\text { Mean } \pm \text { SD }\end{array}$ & $\mathbf{N}$ & $\begin{array}{l}\text { Female } \\
\text { Mean } \pm \text { SD }\end{array}$ \\
\hline Muscle & 45 & $\mathbf{3 2} \pm 1.3$ & 50 & $\mathbf{2 8} \pm 2.3$ \\
\hline GSI & 25 & $\mathbf{1 . 3} \pm 0.7$ & 30 & $\mathbf{5 . 7} \pm 1.8$ \\
\hline Total edible part & 70 & $33.3 \pm 2.4$ & 80 & $33.7 \pm 1.9$ \\
\hline
\end{tabular}

Legend: $\mathrm{n}=$ number of specimen. $\mathrm{SD}=$ Standard deviation.

Table 2: Biochemical composition in male, female and both sexes of S. aspera in Great Bitter Lake.

\begin{tabular}{|l|lc|ll|ll|}
\hline \multirow{2}{*}{} & \multicolumn{2}{|c|}{ Male } & \multicolumn{2}{c|}{ Female } & \multicolumn{2}{c|}{ Combined sexes } \\
& \multicolumn{1}{|c|}{ Muscle } & \multicolumn{1}{c|}{ Gonad } & \multicolumn{1}{c|}{ Muscle } & \multicolumn{1}{c|}{ Gonad } & Muscle & \multicolumn{1}{c|}{ Gonad } \\
\cline { 2 - 7 } & Mean \pm SD & Mean \pm SD & Mean \pm SD & Mean \pm SD & Mean \pm SD & Mean \pm SD \\
\hline Moisture \% & $76.5 \pm 1.3$ & $73.2 \pm 2.9$ & $74.9 \pm 1.3$ & $70.1 \pm 1.9$ & $73.5 \pm 2.8$ & $69.9 \pm 2.2$ \\
proteins \% & $15.7 \pm 1.2$ & $22.6 \pm 1.7$ & $16.4 \pm 2.6$ & $26.5 \pm 2.4$ & $16 \pm 2.2$ & $25.2 \pm 2.8$ \\
Lipids \% & $0.57 \pm 0.08$ & $1.08 \pm 0.09$ & $0.78 \pm 0.04$ & $2 \pm 0.05$ & $0.69 \pm 0.09$ & $1.88 \pm 0.02$ \\
Carbohydrate\% & $0.12 \pm 0.02$ & $0.52 \pm 0.07$ & $0.15 \pm 00.3$ & $0.6 \pm 0.06$ & $0.13 \pm 0.07$ & $0.58 \pm 0.03$ \\
\hline
\end{tabular}

$\mathrm{SD}=$ Standard deviation 


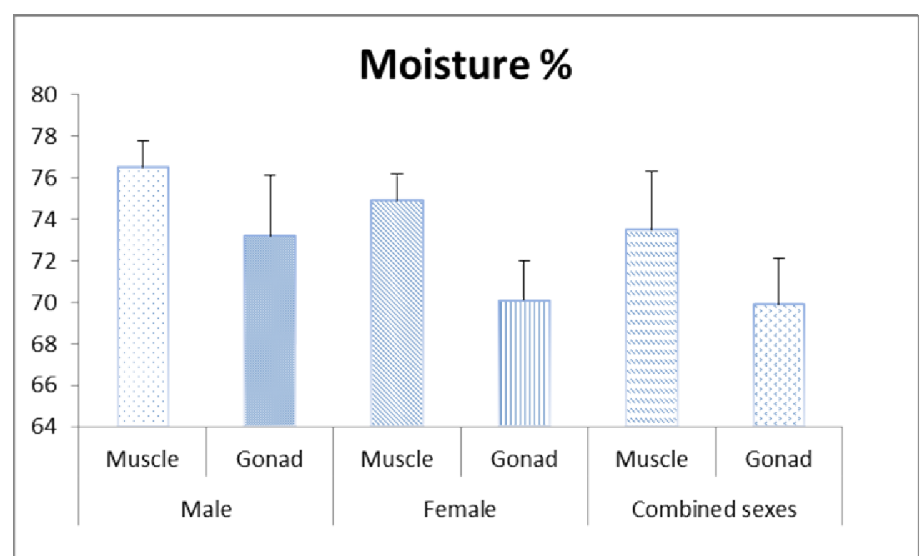

Fig. 2: Moisture in male, female and combined sexes of S. aspera in Great Bitter Lake

\section{Total protein, lipid and carbohydrate}

Total protein, lipid and carbohydrate had been represented in Table 2 and graphically illustrated in Figs. 3, 4 and 5. It is clear that the total content of protein, lipid and carbohydrate attained the similar trend. Comparing edible parts, AOVA test showed that gonad had significantly higher protein, lipid and carbohydrate levels than those of muscle $(\mathrm{p}<0.05)$. Among sexes, ANOVA test noticed that there is a significant difference between male and female $(\mathrm{p}<0.05)$. Female attained a higher levels of protein, lipid and carbohydrate than male.

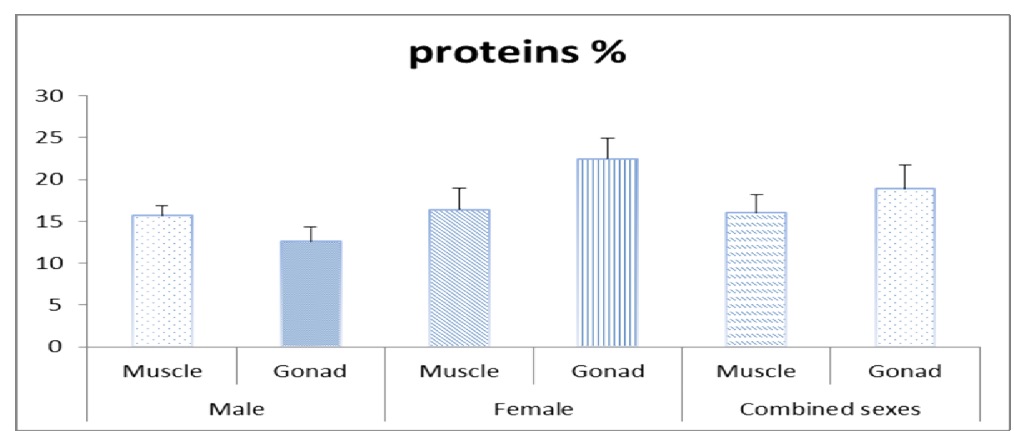

Fig. 3: Protein in male, female and combined sexes of S. aspera in Great Bitter Lake

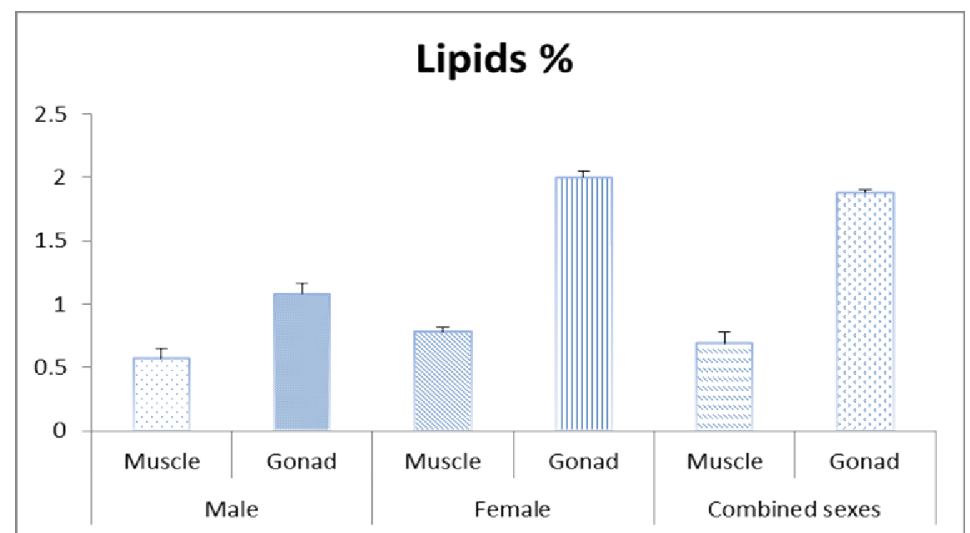

Fig. 4: Lipid in male, female and combined sexes of S. aspera in Great Bitter Lake 


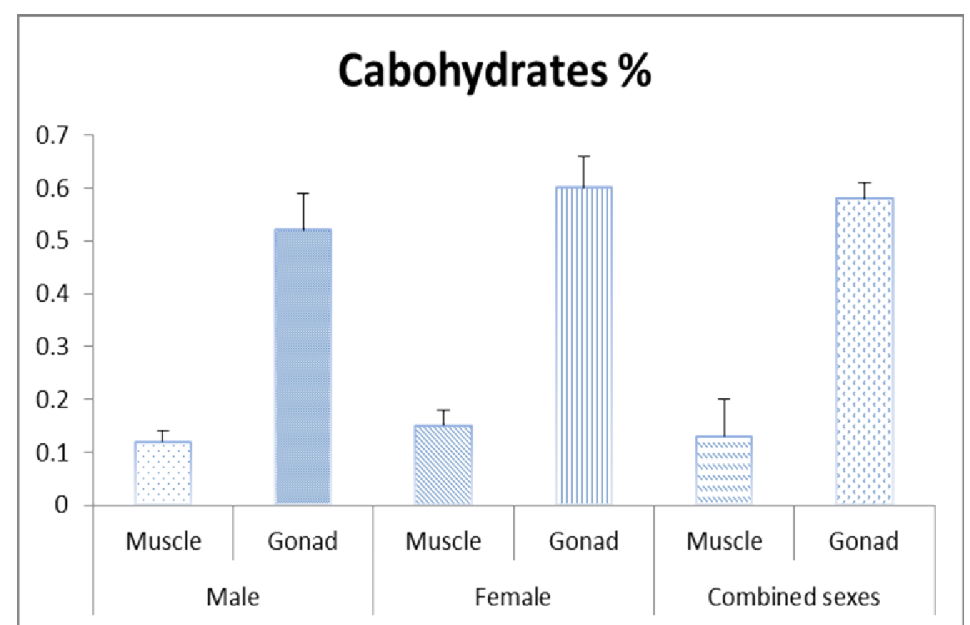

Fig. 5: Carbohydrate in male, female and combined sexes of S. aspera in Great Bitter Lake

\section{DISCUSSION}

Schizophrys aspera crabs have a considerale amount of total edible yield as that contain in the other edible crabs. Wu et al. (2010) studied the total edible yield of the commercial crab Portunus pelagicus in both sexes. The male edible yield of Portunus pelagicus crab was $35.9 \%$. This is in agreement with the present work, which estimate that the male edible yield in the target species was $33.3 \%$. In contrast, female edible yield of $P$. pelagicus was $44.3 \%$ (Wu et al., 2010) whereas in the present work was $33.7 \%$ in female Schizophrys aspera. The green crab Carcinus meditrraneus from the coastal Tunisian water was studied by Cherif et al., 2008. The yield of the combined sexes of Carcinus meditraneus crab showed a mean edible yield of about $34.5 \%$ similar to the edible yield of the present study (33.5\%).

Study of biochemical composition in marine organisms give indication about its nutritial value and it is important for human health. Comparing results of the present study with values reported for other crab species shows differences in protein, lipid and carbohydrate composition (Wen et al., 2001. Celik, 2004). These variations could be explained due to the differences in species (Skonberg \& Perkins, 2002; Gökoalu \& Yerlikaya, 2003, Cherif et al., 2008), sex (Wu et al., 2010), age, nutrient composition of diet, surrounding medium and season (Rosa \& Nunes, 2003; Barrento, et al., 2009; Maulvault et al., 2012). Regarding to the present study, total protein was the major constituent of $S$. aspera, it was higher in gonad than in muscle and also in female more than in male. This coincides with the results of Zaghloul (2003) and VilasoaMartinez et al., (2007).

Lipids are not only the source of energy but also considered as essential nutrients and play an important role for gonad maturation and brood quality (Soudant et al., 1996; Ying et al., 2004 a,b; 2006). In present study, the muscle of the spider crab has more or less similar total lipid to that of other marine crabs, including the dungenes crab Cancer magister (Allen, 1971), the snow crab Chionoecetes opilio (Krzecekowski \& Stone, 1974), the swimming crab Portunus trituberculatus (Su et al., 1996), the mud crab Scylla serrata (Tan et al., 2000), the green crab Carcinus maenas (Naczk et al., 2004), the blue crab Callinectes sapidus (Kuley et al., 2008) and the blue swimmer crab Portunus pelagicus (Wu, 2010). Generally, it was concluded that lipid content was accumulated in gonad more than in muscle.

Regarding to carbohydrate content in the crab studied in the present work, it was found low concentration in muscle and gonad of both sexes. So, it could be explained 
that this species of crab may use lipid as main source of energy instead of carbohydrate. This explanation is in agreement with the findings of Selvin et al. (1998) and Zaghloul (2003) who stated that carbohyadrate content was low in muscle and gonad of the crabs. Blood of crabs stored large quantities of carbohydrate in haemocytes for needs of energy (Selvin et al., 1998). In contrast, Hilmy et al., 1986 indicated that carbohydrate is the major metabolic substrate of crustacea.

\section{CONCLUSION}

The spider crab $S$. aspera collected from Great Bitter Lake, Suez Canal, is not consumed by Egyptian consumers as they are not familiar with it. The present work concludes that muscle and gonad of this crab contain high level of protein and low level of lipid and carbohydrate. These results suggest that spider crab is healthy for human consumption and is also suitable for processing into different crab products.

\section{REFERENCES}

Allen, W. V. (1971). Amino acid and fatty acid composition of tissues of the Dungeness crabs, Cancer magister. J. Fish. Res. Board of Canada 28 (8): 1191- 1195.

Andrés, M., Estévez, A., Rotllant, G. (2007). Growth, survival and biochemical composition of spider crab Maja brachydactyla (Balss, 1922) (Decapoda: Majidae) larvae reared under different stocking densities, prey: larva ratios and diets. Aquacult., 273:494-502.

AOAC, (2012). Official Methods of Analysis of the Association of Official Analytical Chemists, 19th edition. Association of Official Analytical Chemists, Arlington, VA, USA.

Barrento, S.; Marques, A.; Teixeira, B.; Carvalho, M. L.; Vaz-Pires, P. and Nunes, M. L. (2009). Influence of season and sex on the contents of minerals and trace elements in brown crab (Cancer pagurus, Linnaeus, 1758). J. Agri. F. Chem., 57: 3253-3260.

Celik, M.; Tureli, C.; Celik, M.; Yassar, Y.; Erdem, U. and Kucukgulmez, A. (2004). Fatty acid composition of the blue crab (Callinectes sapidus Rathbun, 1896) in the north eastern Mediterranean. F. Chem., 88: 271-273.

Cherif, S.; Fakher, F.; Youssef, G. and Nabil, M. (2008). Fatty acid composition of green crab (Carcinus mediterraneus) from the Tunisian Mediterranean coasts. F. Chem. 111: 930-933.

Folch, J.; Lees, M. and Stanley, G.H.S. (1957). A simple method for the isolation and purification of total lipids from animal tissues. J. Biol. Chem., 266:497-509.

Gökoalu, N. and Yerlikaya, P. (2003). Determination of proximate composition and mineral contents of blue crab (Callinectes sapidus) and swim crab (Portunus pelagicus) caught off the Gulf of Antalya. F. Chem., 80: 495-498.

Guinot, D. (1967). La fauna carcinologique (Crustacea, Brachyura) de L'ocean Indien occidental et de la Mer Rouge. Catalogue Remarques Biogeographic. Mem. I. F. A. N., 77: 235-252.

Hilmy, A. M. H.; El-Zayat, M. A.; Adham, Kh. G. and Abdel Hamid, N.F. (1986). Metabolic activities of the hepatopancreas of the crab, Portunus pelagicus (Linnaeus) after eye stalk ablation. Egypt. J. Hist., 9 (2):329-337.

Ibrahim, N. K. (2007). Studies on fishery and biology of the brachyuran crabs of the Suez Canal. Ph D Thesis (Suez Canal University, Ismailia, Egypt). 
Kanazawa, A.; Teshima, S. and Sakamoto, M. (1985). Effects of dietary lipids, fatty acids, and phospholipids on growth and survival of prawn (Penaeus japonicus) larvae. Aquacult. 50:39-49.

Kochert, A.G. (1978). Carbohydrate determination by the phenol-sulfuric acid method. Handbook of Phycolocical Methods: Physiological and Biochemical Methods. Cambridge University Press, London, Cambridge, 95-97.

Krzecekowski, R.A. and Stone, F.E. (1974). Amino acid, fatty acid and proximate composition of snow crab (Chionoecetes bairdi). J. F. Sci., 39 (2):386-388.

Kuley, E.; OoZogul, F.; OoZogul, Y. and Olgunoglu, A. I. (2008). Comparison of fatty acid and proximate compositions of the body and claw of male and female blue crabs (Callinectes sapidus) from different regions of the Mediterranean coast. Int. J. F. Sci. Nutri., 59(7-8):573-580.

Maulvault, A. L.; Anacleto, P.; Lourenço, H. M.; Carvalho, M. L.; Nunes, M. L. and Marques, A. (2012). Nutritional quality and safety of cooked edible crab (Cancer pagurus). F. Chem., 133:277-283.

Naczk, M.; Williams, J.; Brennan, K.; Liyanapathirana, C. and Shahidi, F. (2004). Compositional characteristics of green crab (Carcinus maenas). F. Chem., 88: 429-434.

Rosa, R. and Nunes, M. L. (2003). Biochemical composition of deep-sea decapod crustaceans with two different benthic life strategies of the Portuguese south coast. Deep-Sea Res. I, 50: 119-130.

Selvin, J.; Ismail, T.; Stephen, J. and George, C. (1997). Biochemical and Nutritional Evaluation of Crab Meat. In: Advances and Priorities in Fisheries Technology. Cochin, India., 358-361.

Skonberg, D.I. and Perkins, B. L. (2002). Nutrient composition of green crab (Carcinus maenus) leg meat and claw meat. F. Chem., 77: 401- 404.

Soudant, P.; Marty, Y.; Moal, J. and Samain, J.F. (1996). Fatty acids and egg quality in great scallop. Aquac. Int., 4:191-200.

Su, X.R.; Li, T.W.; Oyang, F. and Li, P. (1996). Study on the nutritive compositions of Portunus trituberculatus. Acta Nutrimenta Sinica, 18 (3): 342-346.

Tan, D.F.; Wu, G.X.; Lin, Y.X. and Qiu, W.F. (2000). Analysis of nutritional composition of Scylla serrata. J. Fuji. Norm. Univ. Nat. Sci., 16(4):79-84.

Vilasoa-Martine, M.; Lopez-Hernandez, J. and Lage-Yusty, M. A. (2007). Protein and amino acid contents in the crab, Chionoecetes opilio. F. Chem., 103:1330-1336.

Wen, X.; Chen, L.; Ai, C.; Zhou, Z. and Jiang, H. (2001). Variation in lipid composition of Chinese mitten-handed crab, Eriocheir sinensis during ovarian maturation. Comp. Biochem. Physiol., Part B, 130: 95-104.

Wu, G. X.; Zhou, B.; Cheng, Y.; Zeng, C.; Wang, C. and Feng, L. (2010). Comparison of gender differences in biochemical composition and nutritional value of various edible parts of the blue swimmer crab. J. F. Comp. Anal., 23:154-159.

Ying, X.P.; Yang, W.X.; Xu, J.; Lin, F.F. and Santos, A. (2004a). Histological changes and cement gland characters of female pleopod of E. sinensis in different physiological stages. Zool. Res., 25 (3): 256-262.

Ying, X.P.; Zhang, Y.P. and Yang, W.X. (2004b). A comparative study on the fatty acids composition in E. sinensis during the stages of maturation, spawning and abortion. Ocean. Limno. 35 (2):141-148.

Ying, X.P.; Yang, W.X. and Zhang, Y.P. (2006). Comparative studies on fatty acid composition of the ovaries and hepatopancreas at different physiological stages of the Chinese mitten crab. Aquacult., 256:617-623. 
Zaghloul, S. S. (2003). Studies on reproductive biology and rearing of portunid crabs in Suez bay. Ph D Thesis (Suez Canal University, Ismailia, Egypt.

\section{ARABIC SUMMARY}

$$
\begin{aligned}
& \text { المحتوى البيوكيميائي في الاجزاء المأكولة للسرطان العنكبوتي شيزوفرس اسبرا في البحيرات المرة } \\
& \text { بقناة السويس } \\
& \text { نسرين قدري مرسي ابراهيم } \\
& \text { قسم علوم البحار - كلية ألعلوم - جامعة فير قناة السويس }
\end{aligned}
$$

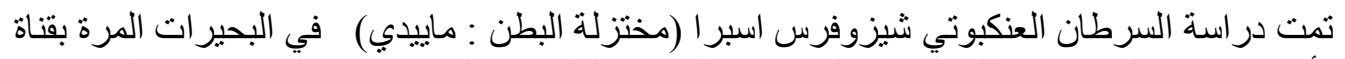

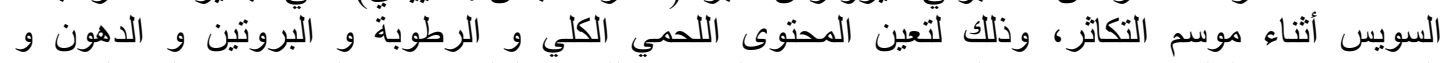

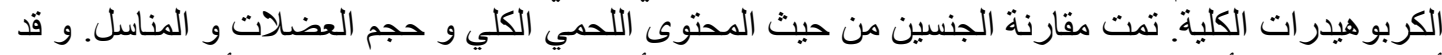

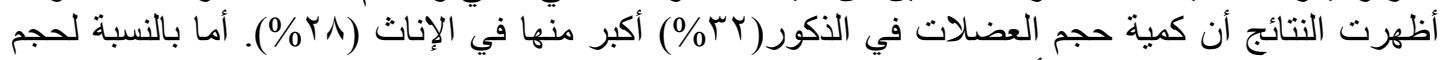

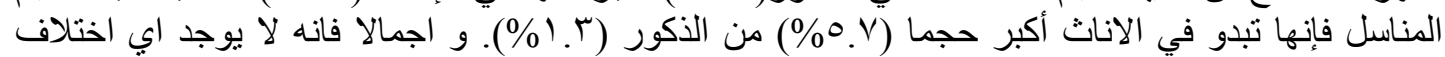

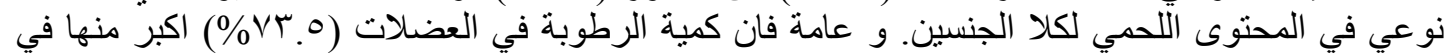

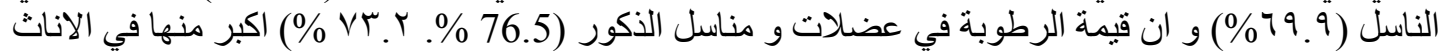

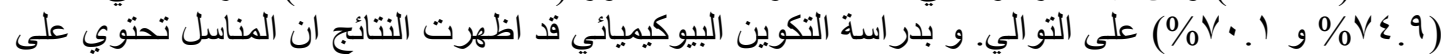

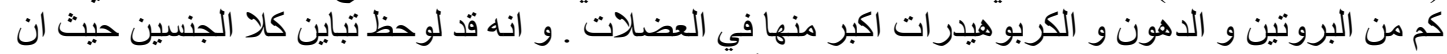

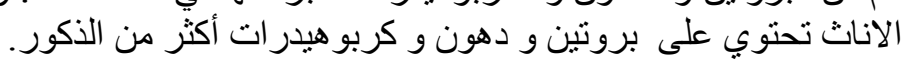

